\title{
Why Do Patients Want Antibiotics and Why Do Physcians Prescribe Antibiotics?: A Cross-Sectional Study In Primary Health Care
}

\section{Hastalar Neden Antibiyotik İster ve Hekimler Neden Antibiyotik Reçete Eder?: Birinci Basamakta Kesitsel Bir Çalışma}

\author{
Feride Derya Şarklı1 , Aylin Baydar Artantaș², Mehmet Uğurlu³ \\ ${ }^{1}$ Eskişehir Tepebaşı Toplum Sağlığı İyiler Family Health Center \\ ${ }^{2}$ Ankara City Hospital, Clinic of Family Medicine \\ ${ }^{3}$ Ankara Yıldırım Beyazıt University Faculty of Medicine, Department of Family Medicine
}

\begin{abstract}
Objectives: The inappropriate use of antibiotics is a worldwide public healthcare problem.

Unfortunately, Turkey has a negative reputation with a particularly high rate of antibiotic prescription. The aim of this study is to determine the factors affecting Turkish primary care physicians in prescribing antibiotics and to evaluate the knowledge levels of the physicians on the rational use of antibiotics.

Materials and Methods: This cross - sectional study was carried out in Family Health Centers and Community Health Centers in 8 different districts in Ankara. A self-reporting questionnaire was administered to the physicians to evaluate their level of knowledge and attitudes towards the rational use of antibiotics. The data obtained were analysed using SPSS 21.0 software.

Results: The study included 200 physicians, comprising 84 (42\%) males and $116(58 \%)$ females. Of the total physicians, $38.5 \%$ stated that they had refused patient's request for antibiotics. Those who had been working for $\geq 11$ years were seen to be affected by 'the patient's expectations and insistence' when prescribing antibiotics and those working for $\leq 10$ years by 'the presence of comorbid disease' $(\mathrm{p} 1=0.044$, $\mathrm{p} 2=0.012)$. The subjects on which the physicians were most lacking in knowledge related to antibiotics were determined to be antimicrobial resistance and cost.

Conclusion: In terms of the rational use of antibiotics, physicians' knowledge level about antibiotics and rational use of antibiotics and their associated behaviour in prescribing antibiotics are extremely important. Therefore, it is important to identify the factors that cause unnecessary antibiotic prescription in order to prevent inappropriate antibiotic use in the population.

Key words: Rational use of antibiotics, primary care, family physician
\end{abstract}

\section{$\ddot{O ̈ z}$}

Amaç: Antibiyotiklerin uygunsuz kullanımı dünya çapında bir halk sağlığı sorunudur. Ne yazık ki, Türkiye özellikle yüksek oranda antibiyotik reçetesi ile olumsuz bir üne sahiptir. Bu çalıșmanın amacı, Türkiye'deki birinci basamak hekimlerinin antibiyotik reçete etmelerinde etkili olan faktörleri belirlemek ve hekimlerin akılcı antibiyotik kullanımı konusundaki bilgi düzeylerini değerlendirmektir. Materyal ve Metot: Bu kesitsel çalışma, Ankara ilinde 8 farklı ilçedeki Aile Sağlığı Merkezleri ve Toplum Sağlığı Merkezleri'nde gerçekleștirildi. Hekimlere bilgi düzeylerini ve akılcı antibiyotik kullanımı ile ilgili tutumlarını değerlendirmek için, kendilerinin cevaplayacağı bir anket uygulandı. Elde edilen veriler SPSS 21.0 yazılımı kullanılarak analiz edildi.

Bulgular: Çalıșmaya 84 (\%42) erkek ve $116(\% 58)$ kadın olmak üzere 200 doktor katıldı. Hekimlerin \%38,5'i hastaların antibiyotik isteğini reddetmiș olduklarını belirttiler. 11 yıl ve daha uzun süredir hekimlik yapanların "hastanın beklenti ve ısrarı"ndan etkilendiği görülürken, 10 yıl ve daha az süredir çalıșanların "eșlik eden hastalık varlığı" ndan etkilendiği görüldü. ( $\mathrm{p} 1=0,044, \mathrm{p} 2=0,012)$. Hekimlerin antibiyotiklerle ilgili en çok antimikrobiyal direnç ve maliyet konularında bilgi eksiklikleri olduğu saptandl.

Sonuç: Antibiyotiklerin rasyonel kullanımı açısından, hekimlerinin antibiyotikler ve antibiyotiklerin akılcı kullanımı ile ilgili bilgi düzeyi ve bunların antibiyotik reçeteleme davranışları ile ilişkisi son derece önemlidir. Bu nedenle, toplumda uygun olmayan antibiyotik kullanımını önlemek açısından gereksiz antibiyotik reçetelenmesine neden olan faktörlerin ortaya çıarılması önemlidir.

Anahtar Kelimeler: Akılcı antibiyotik kullanımı, birinci basamak, aile hekimi 
Why Do Patients Want Antibiotics and Why Do Physcians Prescribe Antibiotics?: A Cross-Sectional Study In Primary Health Care

Yazışma Adresi / Correspondence:

Dr. Aylin Baydar Artantaş

e-mail: draylinbaydar@yahoo.com

Date of submission: 09.11.2018

Date of admission: 14.02 .2019

\section{Introduction}

The use of incorrect, inappropriate, inefficient and high cost drugs is a serious problem worldwide. Rational use of medicines requires that "patients receive medications appropriate to their clinical needs, in doses that meet their individual requirements, for an adequate period of time, and the lowest cost to them and their community" (WHO 1985). ${ }^{1}$ It has been reported that almost half of current medications have been inappropriately prescribed or sold. ${ }^{2}$ One of the most common forms of inappropriate drug use throughout the world are overuse and unnecessary use of antibiotics ${ }^{3}$ The inappropriate use of drugs/antibiotics is a serious healthcare expense worldwide. In addition to cost, another unwanted effect associated with inappropriate antibiotic use is antibiotic resistance. The World Health Organisation (WHO) has reported a worldwide failure of treatment of community and hospital-based infections because of antimicrobial resistance. Antimicrobial resistance affects all areas of health, involves many sectors and has an impact on the whole of society. 4

In Turkey, antibiotics are still one of the most commonly used drug groups although the decline in frequency of antibiotic use in recent years. ${ }^{5}$ In parallel with this, there has been an increase in the development of resistance over the years. In a metaanalysis of studies evaluating antibiotic resistance of E.coli strains in the period 19962012, although there were regional differences, there was seen a significant increase of antibiotic resistance to some antibiotics over the years. ${ }^{6}$

The factors causing inappropriate antibiotic use can be evaluated under the headings of factors related to the physician, the patient and the healthcare service provided by that country. When this subject is examined in Turkey, the reasons for inappropriate antibiotic use can be listed as insufficient awareness, knowledge and education of physicians on the issue, the insistence of patients for the use of antibiotics and problems related to the healthcare system and the social security system. ${ }^{7}$

Just as for every healthcare issue that affects the majority of the community, the inappropriate use of antibiotics must be dealt with first by primary healthcare services. The analysis of knowledge, attitudes and behaviour of primary care physicians who are providing both preventative and therapeutic healthcare services, will provide a robust foundation for interventions to be made by providing a clearer picture of the current status.

The aim of this study is to determine the knowledge level of family physicians about rational use of antibiotics and to identify the factors affecting attitude and the selection of antibiotics, and thereby reveal any deficiencies.

\section{Materials and Methods}

This cross-sectional study was conducted at Family Health Centres (FHC) and Community Health Centres (CHC) in Ankara between 1th October 2012 and 31th December 2012. Taking into consideration potential sociocultural and economic 
Why Do Patients Want Antibiotics and Why Do Physcians Prescribe Antibiotics?: A Cross-Sectional Study In Primary Health Care

differences of the 1254 primary care physicians working in Ankara, 200 physicians from 8 different districts were included in the study. A total of 1254 subjects were identified as 200 physicians with a 0.95 reliability and 0.065 error margin of $\alpha: 0.05$ significance level. A self-reporting questionnaire was administered to the physicians to evaluate their level of knowledge and attitudes towards the rational use of antibiotics. The content of the questionnaire was prepared with reference to national and international literature. A draft form of the questionnaire was created first and applied as a pilot study to 30 family physicians working in FHCs which were outside the scope of the study. Then the necessary corrections were made to obtain the final version of the questionnaire. The Cronbach coefficient of internal reliability for the questions in the questionnaire was determined to be $\alpha=0.776$. The forms were sent to the FHCs and CHCs where the physicians were employed and were delivered to the physicians. Each participant completed the questionnaire themselves. The data obtained in the study were analysed using SPSS 21.0 statistics software. Descriptive statistics were presented as number and percentage values. Chi-square and Anova tests were used for comparisons between groups. A value of $\mathrm{p}<0.05$ was accepted as statistically significant.

Table 1. Professional characteristics of the physicians $(n=200)$

\begin{tabular}{|c|c|c|}
\hline & $\begin{array}{c}\text { Number } \\
(\mathbf{n})\end{array}$ & $\begin{array}{c}\text { Percentage } \\
(\%)\end{array}$ \\
\hline \multicolumn{3}{|l|}{ Place of work } \\
\hline FHC & 174 & 87.0 \\
\hline $\mathrm{CHC}$ & 26 & 13.0 \\
\hline \multicolumn{3}{|c|}{ Time in the profession } \\
\hline 5 years or less & 41 & 20.50 \\
\hline 6-10 years & 27 & $13 \cdot 50$ \\
\hline $11-15$ years & 37 & 18.50 \\
\hline 16-20 years & 47 & 23.50 \\
\hline 21 years and more & 48 & 24.0 \\
\hline \multicolumn{3}{|c|}{ Duration of working at primary care } \\
\hline 5 years or less & 70 & 35.0 \\
\hline 6-10 years & 26 & 13.0 \\
\hline 11-15 years & 38 & 19.0 \\
\hline $16-20$ years & 34 & 17.0 \\
\hline 21 years and more & 32 & 16.0 \\
\hline \multicolumn{3}{|c|}{ Number of patients seen per day } \\
\hline 20 or fewer & 13 & 6.50 \\
\hline $21-40$ & 32 & 16.0 \\
\hline $41-60$ & 59 & $29 \cdot 50$ \\
\hline $61-80$ & 71 & $35 \cdot 50$ \\
\hline 81 and more & 25 & 12.50 \\
\hline
\end{tabular}

FHC: Family Health Center, CHC: Community Health Center 
Why Do Patients Want Antibiotics and Why Do Physcians Prescribe Antibiotics?: A Cross-Sectional Study In Primary Health Care

Permission for the study to be conducted in the FHCs and CHCs was given by the Ankara Public Health Directorate and approval for the study was granted by the NonDrug Clinical Research Ethics Committee of Yildirim Beyazit University Medical Faculty.

\section{Results}

A total of 200 physicians were included in the study, comprising 84 (42\%) males with a mean age of $41.9 \pm 8.6$ years and $116(58 \%)$ females with a mean age of $37.2 \pm 7.8$ years. The professional characteristics of the physicians are presented in Table 1.

When the number of patients that the physicians looked after daily were examined; Approximately $78 \%$ of physicians examined more than 40 patients per day. The most antibiotic-prescribed diagnoses were upper respiratory tract infections (68.5\%), lower respiratory tract infections $(17 \%)$ and urinary system infections (11.5\%) respectively. In general, the factors that influence physicians' decisions to prescribe antibiotics are summarized in Table 2 . Those who have been working for $\geq 11$ years were seen to be affected by the patients' expectations and insistence when prescribing antibiotics and those working for $\leq 10$ years by the presence of comorbid disease $\left(\mathrm{p}_{1}=0.044, \mathrm{p}_{2}=0.012\right)$.

Table 2. Factors affecting the decision of physician to prescribe antibiotics $(n=200)$

\begin{tabular}{|l|c|c|}
\hline & $\begin{array}{c}\text { Number } \\
(\mathbf{n})\end{array}$ & $\begin{array}{c}\text { Percentage } \\
(\%)\end{array}$ \\
\hline Concern about the development of complications & 156 & 78.0 \\
\hline Presence of comorbidity & 123 & 61.50 \\
\hline Concern about not seeing the patient again & 65 & 32.50 \\
\hline Patient age & 52 & 26.0 \\
\hline Patient expectations and insistence & 40 & 20.0 \\
\hline Education level of the patient & 26 & 13.0 \\
\hline Socioeconomic status of the patient & 23 & 11.50 \\
\hline
\end{tabular}

Of the total 200 physicians participating in the study, $38.5 \%$ stated that they had refused patients' requests for antibiotics. The reasons given by patients for requesting antibiotics are shown in Table 3.

Table 3. Reasons given by patients when requesting antibiotics from the physician $(\mathrm{n}=77)^{*}$

\begin{tabular}{|l|c|c|}
\hline & $\mathbf{n}$ & $\mathbf{\%}$ \\
\hline $\begin{array}{l}\text { To be able to have antibiotics from the chemist to be used for } \\
\text { any reason }\end{array}$ & 58 & 75.32 \\
\hline $\begin{array}{l}\text { Thinking that it would be good to have antibiotics that have } \\
\text { previously been used }\end{array}$ & 56 & 72.72 \\
\hline To have antibiotics available at home & 32 & 41.55 \\
\hline To have antibiotics available when going on holiday & 31 & 40.25 \\
\hline To have antibiotics recommended by relatives or friends & 21 & 27.27 \\
\hline
\end{tabular}

${ }^{*}$ The question asking for the reasons that patients requested antibiotics was answered by 77 physicians 
Why Do Patients Want Antibiotics and Why Do Physcians Prescribe Antibiotics?: A Cross-Sectional Study In Primary Health Care

The frequency of physicians consulting a source of information when prescribing antibiotics was reported as "always" by $5.5 \%$, "often" by $34.5 \%$, "sometimes" by $42.5 \%$ and "rarely" by $16.5 \%$. The types of sources of information consulted by physicians when prescribing antibiotics are presented in Table 4.

Table 4. The sources of information consulted by physicians when prescribing antibiotics $(\mathrm{n}=200)$

\begin{tabular}{|l|c|c|}
\hline References consulted & Number & Percentage \\
\hline Vademecum/Turkey drug guidelines & 128 & 64.60 \\
\hline National clinical practice guidelines & 112 & 56.60 \\
\hline Textbooks & 64 & 32.30 \\
\hline International clinical practice guidelines & 54 & 27.30 \\
\hline Drug company representatives & 43 & 21.70 \\
\hline Prescription books & 27 & 13.60 \\
\hline Other & 8 & 4.0 \\
\hline
\end{tabular}

It was seen that physicians working for more than 10 years referred to sources of information less often than physicians with less than ten-year experience when prescribing antibiotics $(\mathrm{p}=\mathrm{0.037})$. The primary reasons why the physicians were not able to benefit from the information sources were "unable to find time due to patient concentration" ( $n=123)$ while the other reasons were "language inability due to current sources of English" ( $\mathrm{n}=32$ ) and "difficulty in accessing resources" $(\mathrm{n}=22)$. A need for training related to rational antibiotic use was stated by $68.5 \%$ of the physicians. Of these, there were a greater number of physicians with less than ten-year experience compared to those with more than ten-year experience in clinical practice $(\mathrm{p}=\mathrm{0.002})$.

The physicans were asked to evaluate their own knowledge level of the spectrum effect, antimicrobial resistance, side-effects, indications, contra-indications, use in pregnancy or breeastfeeding, daily dose, duration of treatment, cost, and drug interactions related to antibiotics. The results of the evaluations are shown in Table 5.

\section{Discussion}

This study reveals the reasons for preferring antibiotics in terms of both physicians and patients. Of course, the main responsibility of prescribing antibiotics belongs to physician and the physician must prescribe antibiotics in accordance with the indications and clinical characteristics of the patient. However, when considering the principle of evidence-based medicine, patient views influence clinical decision-making. Here it is important how and to what extent this effect should be. The most important point in antibiotic prescription should not be overlooked as the correct diagnosis and indication. Irrational reasons should not influence the clinical decision. Unfortunately, however, this study shows that the patient's desire and insistence for antibiotics have a significant impact on the physician's decision to prescribe antibiotics.

According to the results of this study, the primary factor affecting the physician's desicion about prescribing antibiotics was the risk of developing complications. This 
suggests that broad spectrum antibiotics could be prescribed unnecessarily. Other factors were stated as the presence of comorbidities, concern about not seeing the patient again, patient age, the expectations and insistence of the patient, the socioeconomic status of the patient and the education level of the patient. In a study by Wood et al, it was reported that physicians preferred to prescribe broad spectrum antibiotics when the patient was elderly, when there was a comorbidity and when the disease was severe. ${ }^{8}$

Table 5. The knowledge level of physicians related to antibiotics $(\mathrm{n}=2 \mathrm{200})$

\begin{tabular}{|l|c|c|c|c|c|}
\hline & Very poor & Poor & Moderate & Good & $\begin{array}{c}\text { Very } \\
\text { good }\end{array}$ \\
\cline { 2 - 6 } & $\mathrm{n}(\%)$ & $\mathrm{n}(\%)$ & $\mathrm{n}(\%)$ & $\mathrm{n}(\%)$ & $\mathrm{n}(\%)$ \\
\hline Effect spectrum & $\mathrm{o}$ & $4(2)$ & $72(36)$ & $107(53.5)$ & $17(8.50)$ \\
\hline Antimicrobial resistance & $5(2.50)$ & $25(12.50)$ & $90(45)$ & $72(36)$ & $8(4)$ \\
\hline Side-effects & $\mathrm{o}$ & $7(3.50)$ & $75(37.50)$ & $111(55.5)$ & $7(3.50)$ \\
\hline Indications & $\mathrm{o}$ & $3(1.50)$ & $32(16)$ & $132(66)$ & $33(16.50)$ \\
\hline Contra-indications & $\mathrm{o}$ & $9(4.50)$ & $76(38)$ & $100(50)$ & $15(7.50)$ \\
\hline $\begin{array}{l}\text { Pregnancy/breastfeeding } \\
\text { status }\end{array}$ & $1(0.50)$ & $14(7)$ & $54(27)$ & $103(51.50)$ & $28(14)$ \\
\hline Daily dose & $\mathrm{o}$ & $1(0.50)$ & $37(18.50)$ & $121(60.50)$ & $41(20.50)$ \\
\hline $\begin{array}{l}\text { Total duration of } \\
\text { treatment }\end{array}$ & $\mathrm{o}$ & $5(2.50)$ & $42(21)$ & $117(8.50)$ & $36(18)$ \\
\hline Costs & $12(6)$ & $47(23.50)$ & $80(40)$ & $47(23.50)$ & $14(7)$ \\
\hline Drug interactions & $2(1)$ & $38(19)$ & $100(50)$ & $54(27)$ & $6(3)$ \\
\hline Manner of application & $\mathrm{o}$ & $3(1.50)$ & $28(14)$ & $111(57)$ & $55(27.50)$ \\
\hline
\end{tabular}

The working conditions of physicians constitute a factor affecting antibiotic prescription behaviour. Previous studies have shown that as the daily number of patients seen by physicians increases, so there is an increase in the rate of antibiotic prescriptions. ${ }^{9,10}$ The physicians participating in the current study stated that they had prescribed a greater number of antibiotics on days when they examined high number of patients. In this study, it was seen that more than half of the family physicians were examining more than 6o patients per day. According to these numbers, maximum of 8 minutes can be allocated for each patient without a break. Moreover, when numbers increase even more, the time could be reduced to 4-5 mins per patient. This high number of patients and thereby very limited time for each patient is an important factor in reduced quality of healthcare.

Another factor related to working conditions is the laboratory availability for physicians. In the decision to prescribe antibiotics, one of the most useful components is the results of cultures and antibiogram when necessary. When there is no possibility of taking a culture there may be an increase in the frequency of prescribing unnecessary antibiotics. ${ }^{1,12}$ The current status in Turkey is that many FHCs do not have facilities for taking cultures. Rapid and reliable diagnostic testing is also insufficient. Patients are referred to hospitals when it is considered necessary by the physician. All the physicians participating in this study who were working in FHCs stated that they 
did not have the facilities for taking cultures. This can be considered a reason for the inapproriate prescription of antibiotics in some cases. Struggling with the increasing antibiotic resistance, one of the core actions that was reported by WHO is building laboratory capacity for rapid and reliable diagnostic testing. ${ }^{13}$ WHO updated this recommendation as "Developing the economic case for sustainable investment that takes account of the needs of all countries, and increase investment in new medicines, diagnostic tools, vaccines and other interventions" in Global Action Plan on Antimicrobial Resistance in 2015. ${ }^{4}$ Another advantage of using diagnostic testing is that when there is negative result it can be easier for the physician to persuade the patient that antibiotics are not necessary. It has been stated in many studies that patients sometimes put pressure on doctors to prescribe antibiotics. ${ }^{14-20}$ It has even been claimed that the best way to change the behaviour of physicians in prescribing antibiotics is to change the expectations of patients on this issue. ${ }^{21} \mathrm{~A}$ study in the UK showed that the prescribing of unnecessary antibiotics could be avoided by the physician giving a running commentary on the examination findings to eliminate the patient's expectations for antibiotics. ${ }^{15}$ The taking of a clinical decision together by the physician and patient is an inseperable part of patient-centred care and the tendency of physicians in this direction also decreases the rate of prescribing antibiotics. ${ }^{22}$ These examples demonstrate that a well-structured patient-physician relationship will greatly reduce the expectations of antibiotics for patients. In our study, it appears that patients often have the desire to prescribe an antibiotic that they have previously used. There is also a tendency to have antibiotics for use in case of need in the absence of any complaints in the current status.

Another point to note about this study is that those who have been in practice for more than 10 years are more affected by patients' expectations and insistence when prescribing antibiotics. In literature there are studies that support this finding. ${ }^{10} \mathrm{This}$ may be due to the fact that physicians who have more experience in their profession may be exposed to patients' requests for longer periods of time, and may lose their resistance at some point and do not want have problems with these patients. This situation may also be related to the burn out of those physicians. Physicians with experience of less than 10 years were more affected by comorbidities of the patients when prescribing antibiotics, which may have been due to feeling that they had insufficient experience of managing multiple diseases. In a study in UK, it was noticeable that the patients for whom antibiotics were prescribed were elderly, had comorbidities and were taking medication for other reasons for the past one year. ${ }^{23}$

In the current study, it was determined that approximately half of the physicians had received training related to rational antibiotic use, and nearly half of these stated that the training had been received after graduation. In a 2013 study by Parlak et al this rate was found lower. ${ }^{24}$ It seems that the Ministry of Health has given more importance to the issue in recent years. Interventions such as conferences organised to raise awareness, mandatory sessions related to rational antibiotic use at congresses have been reflected positively in the number of physicians receiving training. In addition to postgraduate training, continuous updating is also very important. Clinical practice guidelines that physicians can easily reach whenever they want will prevent the unnecessary prescribing of antibiotics to some extent. In Turkey, the number and quality of clinical practice guidelines for primary care is not at the desired level. ${ }^{25}$ 
Insufficient national resources, unavailability of international resources and insufficient language capabilities reduce the rates of use of sources of information on this subject. In the current study, the reference used most frequently by the physicians was reported to be the Vademecum/Turkey drug guidelines, followed by national diagnosis and treatment guidelines and textbooks related to the subject. In another study conducted in another province in Turkey, while the first references consulted were similar, as textbooks and journals, other sources of information were determined to be visits and meetings of drug companies and congresses-seminars. That study also determined that factors affecting the prescribing of inapproriate antibiotics were insufficient training, not using a laboratory and not following guidelines. ${ }^{24}$ When the knowledge level of the physicians related to antibiotics was examined, the worst part were seen to be cost and antibiotic resistance. The basic elements of rational antibiotic use must certainly be known by physicians. It will be more useful to concentrate on the points where doctors are lacking in training to be given. In terms of antimicrobial resistance, national and regional studies should be given priority and these should be shared with field practitioners. The inappropriate use of antibiotics is a global public health problem. Therefore, international institutions make common plans related to the issue. Although international institutions are working in collaboration, there is a need for national multidisciplinary organs to coordinate the policies of countries related to their own drug use. Efforts on this subject in Turkey are mainly managed by the Ministry of Health. However, a greater role in sharing the responsibility should be taken by universities, nongovermental organisations and patient associations.

As a result, when we look at the percentage of antibiotic prescribing of family physicians by years; It is observed that the percentage of antibiotic prescriptions, which was $34.9 \%$ in 2011, started to decrease especially since 2013 . According to the latest data, the percentage of prescribing antibiotics of the family physicians is $25 \%$. This positive development, of course, shows that the Ministry of Health's initiatives on this issue are effective. However, when considering international statistics, Turkey is still above the average of OECD countries in terms of the use of antibiotics. ${ }^{26}$ Therefore, it is important to support the researches about physicians' attitudes towards antibiotic prescribing as well as the causes of antibiotic use habits of patients. With such studies, in addition to detecting the status, the data obtained will be useful in achieving the long-term targets. There are many studies related to the issue of antibiotic prescribing habits of family physicians and the inappropriate prescription of antibiotics. Although studies have been carried on this issue in Turkey, they have generally been conducted as analysis of prescriptions. Also many studies conducted at primary care were carried out in the period before the practice of family medicine entered into force. In this context, in Turkey, the current study can be considered the one of the first studies to have examined the behaviour of family physicians in respect of their behaviour in prescribing antibiotics and of their knowledge level on the rational use of antibiotics. In this study, rather than examining the prescriptions and the suitability of the agents prescribed, the factors affecting the prescribing of antibiotics were identified and the knowledge level of the principles of rational antibiotic use were evaluated. The reasons given by patients requesting antibiotics from the physician were also investigated. We think it is important to consider the results of our study in this context. 
Why Do Patients Want Antibiotics and Why Do Physcians Prescribe Antibiotics?: A Cross-Sectional Study In Primary Health Care

\section{References}

1. Management Sciences for Health.2012.MDS-3:Managing Access to Medicines and Health Technologies.Chapter 27 Managing for rational medicine use.Arlington, VA:Management Sciences for Health.2012:517-8.

2. Management Sciences for Health.2012.MDS-3:Managing Access to Medicines and Health Technologies.Chapter 2 Historical and institutional perspective. Arlington, VA:Management Sciences for Health. 2012:33.

3. World Antibiotic Awareness Week, 12-18 November 2018. http://www.who.int/campaigns/world-antibiotic-awareness-week/2017/launch-event/en/ (Accessed 5 July 2018)

4. Global Action Plan on Antimicrobial Resistance. World Health Organization.Printed by the WHO Document Production Services, Geneva, Switzerland.2015:8.

5. Key Indicators. Turkish Pharmaceutical Market. Pharmaceutical Manufacturers Association of Turkey (IEIS).http://www.ieis.org.tr/ieis/tr/indicators/33/turkiye-ilacpazari/(Accessed 5 July 2018).

6. Aykan Ș. B, Çiftçi İ. H. Türkiye'de İdrar Kültürlerinden İzole Edilen Escherichia coli Suşlarının Antibiyotiklere Direnç Durumu: Bir Metaanaliz. Mikrobiyol Bul 2013; 47(4):603-18.

7. Kayhan Tetik B, Baydar Artantaş A. Uygunsuz antibiyotik Kullanımı. Turkish Medical Journal, 2011:5(3):136-8.

8. Fiona Wood, Sharon Simpson, Christopher C Butler. Socially responsible antibiotic choices in primary care: a qualitative study of GPs' decisions to prescribe broad-spectrum a fluroquinolone antibiotics. Family Practice 2007; 24: 427-34.

9. Öztürk II, Avcı IY, Çoşkun Ö, Gül HC, Eyigün CP. Birinci Basamak Sağlık Kurulusunda Görev Yapan Hekimlerin Sık Görülen Toplum Kaynaklı Enfeksiyonlardaki Antibiyotik Seçimleri ve Bunu Etkileyen Faktörler Firat Tip Dergisi 2008;13 (4): 255-6o.

10. Cadieux G, Tamblyn R, Dauphinee D, Libman M. Predictors of inappropriate antibiotic prescribing among primary care physicians. CMAJ, 2007; vol. 177 no. 8: 877-83.

11. George CE, Norman G, Ramana GV, Mukherjee D, Rao T. Treatment of uncomplicated symptomatic urinary tract infections: Resistance patterns and misuse of antibiotics. J FamilyMed Prim Care 2015;4:416-21.

12. Mishra B, Srivastava S, Singh K, Pandey A, Agarwal J. Symptom-based diagnosis of urinary tract infection in women: are we over-prescribing antibiotics? Int J Clin Pract. 2012;66(5):493-8.

13. World Health Day 2011: policy briefs. Strengthen Surveillance and Laboratory Capacity.World Health Organization. 2011. http://www.who.int/world-health-day/2011/en/ (Accessed 13 July 2018).

14. Gonzalez-Gonzalez C, López-Vázquez P, Vázquez-Lago JM, et al. Effect of Physicians' Attitudes and Knowledge on the Quality of Antibiotic Prescription: A Cohort Study. Aziz RK, ed. PLoS ONE. 2015;10(10). eo141820. doi:10.1371/journal.pone.0141820.

15. Mohammed Mustafa, Fiona Wood, Christopher C. Butler, Glyn Elwyn. Managing Expectations of Antibiotics for Upper RespiratoryTract Infections: A Qualitative Study. Ann Fam Med 2014;29-36.

16. Mangione-Smith R, McGlynn EA, Elliott MN, McDonald L, Franz CE, Kravitz RL. Parent Expectations for Antibiotics, Physician-Parent Communication, and Satisfaction. Arch Pediatr Adolesc Med.2001;155(7):800-6.

17. Scott JG, Cohen D, DiCicco-Bloom B, Orzano AJ, Jaen CR, Crabtree BF. Antibiotic use in acute respiratory infections and the ways patients pressure physicians for a prescription. J Fam Pract. 2001 Oct; $50(10): 853-8$.

18. Hamm RM, Hicks RJ, Bemben DA. Antibiotics and respiratory infections: are patients more satisfied when expectations are met? J Fam Pract. 1996 Jul;43(1):56-62.

19. Macfarlane J, Holmes W, Macfarlane R,Britten N. Influence of patients' expectations on antibiotic management of acute lower respiratory tract illness in general practice: questionnaire study. BMJ 1997;315:1211.

20. Björkman I, Berg J, Viberg N, Stålsby Lundborg C. Awareness of antibiotic resistance and antibiotic prescribing in UTI treatment: a qualitative study among primary care physicians in Sweden. Scand J Prim Health Care. 2013 Mar;31(1):50-5. 
Why Do Patients Want Antibiotics and Why Do Physcians Prescribe Antibiotics?: A Cross-Sectional Study In Primary Health Care

21. States Guillermo V. Sanchez, Rebecca M. Roberts, Alison P. Albert, Darcia D. Johnson, Lauri A. Hicks. Effects of Knowledge, Attitudes, and Practices of Primary Care Providers on Antibiotic Selection, United States. Emerg Infect Dis. 2014 Dec; 20(12): $2041-7$.

22. Coxeter P, Del Mar CB, McGregor L, Beller EM, Hoffmann TC. Interventions to facilitate shared decision making to address antibiotic use for acute respiratory infections in primary care. Cochrane Database Syst Rev. 2015 Nov 12;(11):CDo10907. doi:10.1002/14651858.CDo10907.pub2.

23. Meropol S.B, Localio A.R, Metlay J.P. Risks And Benefits Associated With Antibiotic Use For Acute Respiratory Infections: A Cohort Study Annals Of Family Medicine.2013; vol:11,number 2:165-72.

24. Parlak E, Çayır Y, Ertürk A. Aile Hekimlerinin akılcı antibiyotik kullanımı açısından durumları: Erzurum'dan kesitsel bir çalışma. Euras J Fam Med 2013;2(1):27-32.

25. Baydar Artantas A, Kahveci R, Sunay D, Caylan A. Quality assessment of primary care guidelines inTurkey. HealthMED. 2011; 5(6): 1565-73.

26. Health Statistics Yearbook 2017.Chapter 9.Pharmaceutical Statistics. Republic of Turkey Ministry of Health General Directorate of Health Information Systems. Ministry of Health Publications No: 1107. Edition: Kuban Matbaacilık Yayıncılık, Ankara,2018. 